\title{
Land Evaluation of an Agricultural Landscape in Dingyadi District, Sokoto State, Nigeria
}

\author{
* 1M.B. Sharu, ${ }^{2}$ M. Yakubu, ${ }^{3}$ S.S. Noma and ${ }^{4}$ A.I.Tsafe \\ 1Department of Agricultural Science, Shehu Shagari College of Education, Sokoto \\ 2Faculty of Agriculture, Ibrahim Badamasi Babangida University, Lapai, Niger State, Nigeria \\ ${ }^{3}$ Department of Soil Science and Agricultural Engineering, Usmanu Danfodiyo University, Sokoto, Nigeria \\ 4Department of Pure and Applied Chemistry, Usmanu Danfodiyo University, Sokoto, Nigeria \\ [Corresponding Author, E-mail: mbsharu12@gmail.com; 留: +2348185066077]
}

\begin{abstract}
A semi-detailed survey was conducted to evaluate the soils of an agricultural landscape in Dingyadi area of Sokoto State. Three soil mapping units TLL1, TUP2 and TUP3 were identified on the basis of land forms and surface texture. USDA land capability classification, Fertility capability classification and land suitability classification were use for this purpose. The soils were grouped into various Land capability classes as class IVw, IIIse, and IIles for TLL 1, TUP 2 and TUP3 respectively. In land fertility capability classification (FCC) soil units TLL 1, TUP 2 and TUP3 were classified as LSg, Lde and Sde respectively. The suitability of the soil was assessed for two major crops (Cowpea and pearl millet) grown in the area TUP2 and TUP3 are rated moderately suitable for cowpea and pearl millet (S2s) while TLL 1 was rated currently not suitable (N1Sw) for cowpea and pearl millet because of limitation of wetness. Management practices such as periodic monitoring of soil quality, adding organic manure and guided inorganic fertilizer use have been recommended for improve productivity.

Keywords: Land, Suitability, Capability; Fertility, Classification, Evaluation
\end{abstract}

\section{INTRODUCTION}

Some 10,000 years of irrational land use by humans has transpired, with no objective beyond seeking maximum yield from each kind of soil use. As a result, the soil has reached the present day intensity degraded to the point that a great part of arable land, especially in arid and semi- arid regions, is in a situation of irreversible deterioration. To stop this dramatic trend, the only solution is to institute rational soil-use that is, to use each soil in a way that best suit its characteristics and to programme its management for minimal deterioration. This is precisely the final aim of land evaluation (Dorronso, 2010). Land evaluation is an applied classification system that assesses the capacity of the soil for its optimal use- that is, to derive maximum benefits with minimum degradation. This has been defined by Van Diepen et al. (1991) to as "any method to explain or predict the use potential of land". The evaluation of land is normally carried out to determine their suitability for specific uses. The information obtained can be used for a more realistic land use recommendation and present their constraints (FAO, 1995; Abdulkadir, 1998). It also enables management guidelines in order to promote a more sustainable use of the soil and environmental resources (Maniyunda et al 2007). The pressing demand for food and space from a growing population has created a competition for land. In many developing countries, fuel-wood, cash crops, timber for construction and grazing for livestock compete with food crops for space, not only on the better quality land but also the marginal areas (Verheye, 2000). In addition, modern agriculture requires that farmers have some direct or indirect knowledge of the capability and nutrient status of the soils to be utilized. Such information enables the farmer to make informed choices on crops and/livestock to be raised that are technically feasible (Harrison, 1987). This has given rise to soil evaluation studies prior to crop production and other agricultural land uses. The need for land evaluation arose from the fact that soil classification, soil map and the accompanying legends do not meet the needs of farmers and other land users (Ogunkunle, 1993). At presence, the importance of land evaluation should be seen in the context of land becoming a scarce and non renewable natural resource which is highly desired, for which there is a growing competition and which, obviously holds a proper exchange value (Verheye, 2000). Dingyadi district is a farming community close to Sokoto urban centre and the increasing demand for urban land is putting much pressure on the valuable agricultural land and thus the need for evaluation. The objective of this study is to evaluate the soils of an agricultural landscape in Dingyadi District for the proper agricultural uses. 


\section{MATERIALS AND METHODS Study Area}

The study site is in the Dingyadi District of Bodinga Local Government Area of Sokoto State, about 15 kilometers away from the state capital $\left(13^{0} 56^{1} \mathrm{~N}, 130^{\circ}\right.$

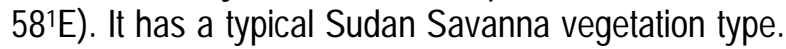
The area is intensively cultivated to array of crops such as onion, tomato, cowpea and millet. The length of growing period is 90-150 days (Ojanuga, 2006). The climate of Sokoto State is wet and dry; generally hot semi-arid tropics in Coppen classification of AW type (Sombroek and Zonneveld, 1971). It is characterized by long dry season from October through May/June and a short but intensive wet season from May/June through September with a mean annual rainfall slightly below $750 \mathrm{~mm}$. The rainfall pattern shows a marked seasonal variation with a single peak reaching maximum in August (Kowal and Knabe, 1972). The temperature fluctuates within a range from $16{ }^{\circ} \mathrm{C}$ during cold nights to over $40{ }^{\circ} \mathrm{C}$ during the hot days. The relative humidity during dry season is about $15-20 \%$ and reaches up to $70-75 \%$ during the rainy season. Most of the arable land consists of well drained upland with flat or slightly undulating topography which supports one growing season under rainfall conditions (Singh and Babaji, 1989).

Geologically the area is underlain by Tertiary Sedimentary rocks of the Gwandu formation. The formation consists of semi- consolidated fine to coarse grained sand with clay-shale, clayed grits, sandstones and clay (FDALR, 1985).

\section{Field study}

A semi-detailed soil survey was conducted in the area at a scale of 1:25,000 following the procedures described in Wilding and Dress (1983). Using ranging poles, pegs and GPS instruments, transects at 100 meters intervals were constructed at right angles $\left(90^{\circ}\right)$ to the either side of the baseline. Pegging was then carried out on these intervals on a fixed grid pattern. Auger borings were made to examine and describe the soils consistently at 100 meters interval along each traverse. Observations relating to morphological properties of the soils, physiographic position, topography, colour, were used to establish the soil boundaries. Two modal profile pits were excavated in each identified soil mapping unit, the second pit in each unit serving as duplicate. The soil profiles were described according to FAO (2006) manual. Demarcation of the different soil mapping units was based on landscape and surface soil characteristics such as texture, structure, consistency etc. The entire mapped area was resolved into three soil mapping units namely TLL 1, TUP 2 and TUP 3. Based on the data obtained from the soil survey, the soils/ land at Dingyadi District were subsequently classified into the various capability classes such as the USDA Land Capability Classification, Fertility Capability Classification (FCC) and Land Suitability Capability Classification.

\section{Laboratory analyses}

Soil samples collected during field studies were subjected to physical and chemical analyses. Particle sizes were determined with the Bouyoucos hydrometer method as described by Gee and Bauder, (1986) while bulk density was determined using the core sampler (Blake and Hartge, 1986). Particle density was determined by the use of Pycnometer $\left(25 \mathrm{~cm}^{3}\right)$ method (Blake, 1965). Total porosity was calculated from particle and bulk densities using the relationship established by Vomocil (1965) i.e. $N=100\{1-\mathrm{Db} / \mathrm{pd}\}$, where $\mathrm{N}=$ porosity, $\mathrm{Db}=$ bulk density, $\mathrm{pd}=$ Particle density Soil pH was measured in a 1:1 soil water with glass electrode $\mathrm{pH}$ meter. Organic carbon was determined by the Dichromate wet oxidation method (Nelson and Summers, 1982). The cation exchange capacity (CEC) was determined by saturating the soil with normal neutral ammonium acetate solution. Base saturation was calculated as the sum of total exchangeable bases divided by $\mathrm{NH}_{4} \mathrm{OAC}$ cation exchange capacity and expressed as a percentage (Page et al., 1982). Total nitrogen was determined by the macro-kjeldahl digestion distillation methods.

\section{RESULTS AND DISCUSSION \\ Morphological and Physical Properties}

Selected morphological and physical properties of the soils in selected pedons are presented in Table 1. The soils are deep with depth to soil horizon of $>100 \mathrm{~cm}$ in all pedons except in pedon 5 ( Typic Ustorthents) which has a depth of $<50 \mathrm{~cm}$ as a result of ironstone (lithic contact). Pedons 1 and 3 are texturally sandy loam in the surface and sandy clay loam in the subsurface while pedon 5 is generally sandy. The soils in pedons 1 and 3 are structurally subangular blocky in shape with moderate and fine grade and class respectively. Soils in pedon 5 are single grain because of their sandy nature. Consistence is generally friable to loose in all the soils. 
Mean bulk density values in pedons 1, 3 and 5 are $1.58,1.55$ and $1.44 \mathrm{Mgkg}^{-1}$ respectively. The values are generally moderate. Porosity is generally low with mean values of 36,38 and $42 \%$ for pedons 1,3 and 5 respectively. The low porosity values could be attributed to the sandy nature of the soils.

Table 1: Some Morphological and Physical Properties of the soils in Selected Pedons of Dingyadi District

\begin{tabular}{|c|c|c|c|c|c|c|c|c|}
\hline Pedon & Horizon & $\begin{array}{l}\text { Depth } \\
\text { (cm) }\end{array}$ & $\begin{array}{l}\text { Textural } \\
\text { class }\end{array}$ & Structure* & Consistence* $^{*}$ & $\begin{array}{l}\text { Bulk } \\
\text { density } \\
\left(\mathrm{mgkg}^{-1}\right)\end{array}$ & $\begin{array}{l}\text { Particle } \\
\text { Density } \\
\left(\mathrm{mgkg}^{-1}\right)\end{array}$ & $\begin{array}{l}\text { Porosity } \\
\text { (\%) }\end{array}$ \\
\hline & \multicolumn{8}{|c|}{ TLL1 (Typic Endoaqualfs) } \\
\hline & Ap & $0-30$ & LS & 1fsbk & $\mathrm{Fr}$ & 1.48 & 2.47 & 40 \\
\hline & $A B$ & $30-49$ & LS & $2 f s b k$ & $\mathrm{Fr}$ & 1.62 & 2.41 & 33 \\
\hline & $B$ & $49-73$ & $\mathrm{SCL}$ & 3fsbk & $\mathrm{Fr}$ & 1.60 & 2.41 & 34 \\
\hline & Bt1 & $73-104$ & $\mathrm{SCL}$ & 2fabk & Lo & 1.50 & 2.47 & 39 \\
\hline & Bt2 & $104-110$ & $\mathrm{SCL}$ & $2 \mathrm{csbk}$ & $\mathrm{Fr}$ & 1.70 & 2.54 & 33 \\
\hline Mean & & & & & & 1.58 & 2.46 & 36 \\
\hline \multicolumn{9}{|c|}{ TUP2 Typic Haplustepts } \\
\hline \multirow[t]{5}{*}{2} & Ap & $0-18$ & LS & $1 \mathrm{fsbk}$ & $\mathrm{Fr}$ & 1.51 & 2.47 & 39 \\
\hline & $A B$ & $18-27$ & LS & $2 \mathrm{fbk}$ & $\mathrm{Fr}$ & 1.57 & 2.54 & 38 \\
\hline & 2Bw1 & $27-66$ & $\mathrm{SCL}$ & $2 f s b k$ & $\mathrm{Fr}$ & 1.62 & 2.47 & 34 \\
\hline & $2 B w 2$ & $66-135$ & SL & $2 f s b k$ & $\mathrm{Fr}$ & 1.56 & 2.47 & 37 \\
\hline & 2Bw3 & $135-204$ & $\mathrm{SCL}$ & 1fsbk & $\mathrm{Fr}$ & 1.49 & 2.54 & 41 \\
\hline \multirow[t]{2}{*}{ Mean } & & & & & & 1.55 & 2.50 & 38 \\
\hline & \multicolumn{8}{|c|}{ TUP 3 Typic Ustorthents } \\
\hline \multirow[t]{3}{*}{3} & $A p$ & $0-11$ & S & $\mathrm{Sg}$ & Lo & 1.51 & 2.54 & 41 \\
\hline & $A B$ & $11-40$ & S & $\mathrm{Sg}$ & $\mathrm{Fr}$ & 1.40 & 2.47 & 43 \\
\hline & $\mathrm{B}$ & $40-43$ & S & $\mathrm{Sg}$ & $\mathrm{Fr}$ & 1.41 & 2.41 & 41 \\
\hline Mean & & & & & & 1.44 & 2.47 & 42 \\
\hline
\end{tabular}

*Determined at moist condition, Note: symbols or codes according to FAO, 2006

Structure: $0=$ structureless, 1=weak, 2=moderate, $3=$ strong, sg=single grain, csbk = coarse subangular blocky, fsbk= fine, subangular blocky,.Consistence: Lo=loose, Fr=friable, Texture: LS-=Loamy sand, SCL=Sand Clay loam, S= sand

\section{Land Capability Classification}

The soils have been classified into various land capability classes as presented in Table 2 and Figure 1. Soil unit TLLI is classified as IVw because they have slight limitation that could restrict their use in the form of wetness. They also have a texture of sandy loam at surface, have low infiltration rate, high water table and are poorly drained during the rainy season. The limitation could be overcome by introducing water loving crops (hydrophytes e.g. rice) and also ensuring adequate surface and subsurface drainages. Soil unit TUP2 is classified as Illes class due to limitations that could reduce the choice of crops. The subclass ' $e$ ' indicates susceptibility to erosion and 's' shows low moisture holding capacity. The soils are generally loamy sand with high infiltration rates. Their sandy nature could result in low storage capacity of moisture and nutrients. Therefore, in line with this, the soils could be good for agriculture if organic matter level is increased.

Table 2: Land Capability Classification of the soils of an Agricultural landscape in Dingyadi district

\begin{tabular}{lll}
\hline Soil unit & $\begin{array}{l}\text { Capability } \\
\text { class }\end{array}$ & Limitations \\
\hline TLLI & IVw & Wetness \\
TUP2 & Illes & Erodibility, Soil \\
TUP3 & Illes & Erodibility, Soil, root depth \\
\hline
\end{tabular}

Soil unit TUP3 is classified as Illes because they require some careful management. The subclass ' $e$ ' indicates they are susceptible to erosion while the 's' subclass shows limitation within the rooting zone. The soils are predominantly sandy with an impermeable layer at the subsurface (iron stone). These limitations could result to low root penetrations and surface run off could be high, there by leading to erosion problem. 


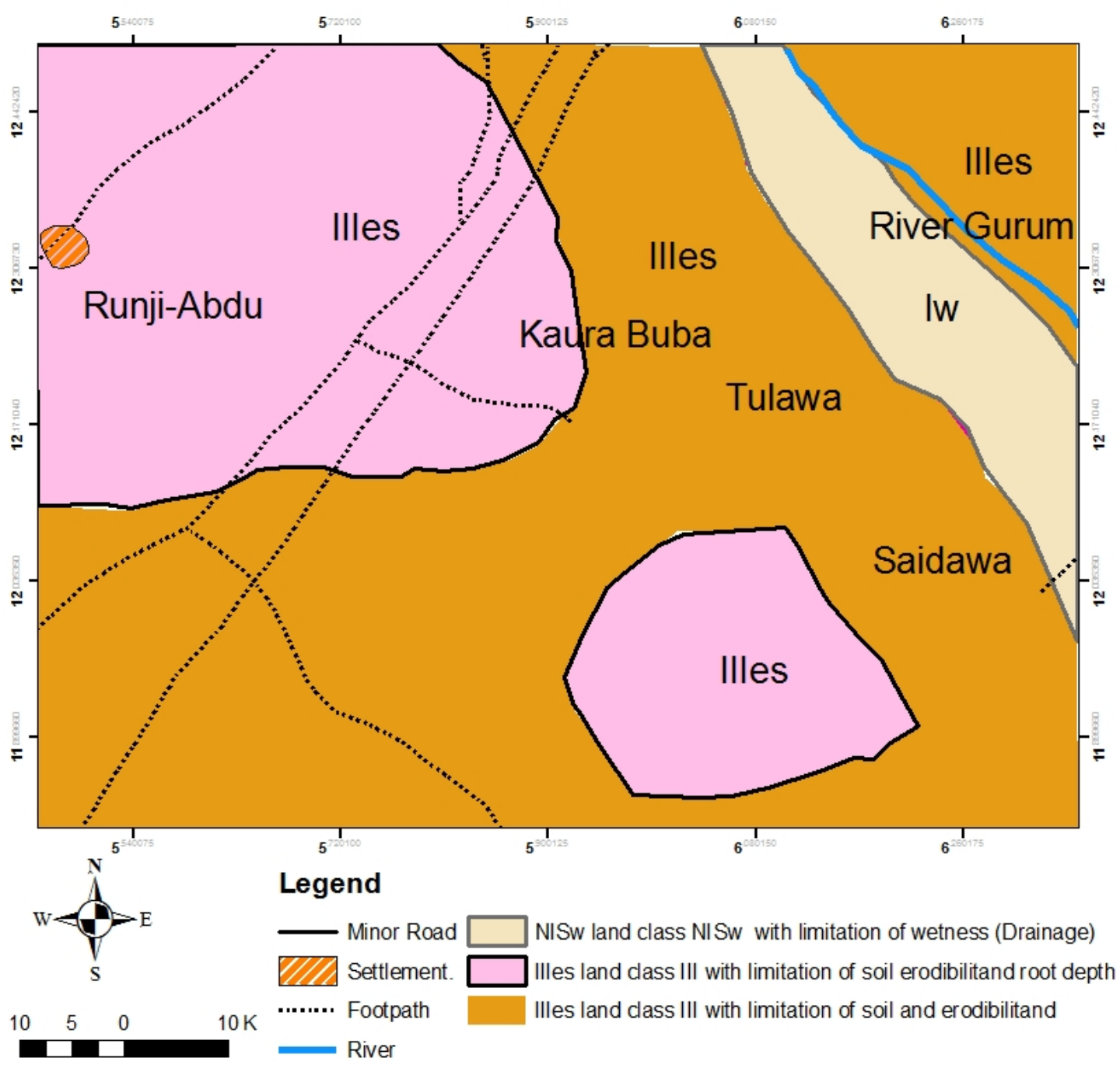

Figure 1: Land capability map of the soils of an Agricultural landscape in Dingyadi district

\section{Land Suitability Classification}

The suitability of the soils was assessed for two major crops (cowpea and millet) grown in the area following the method described in FAO (1985) manual and presented in Figure 2. Classes were defined with regards to the number and intensity of the limitations. Soil units are placed according to their suitability for production of specific crop using the soil physical, morphological and some chemical characteristics (Tables 1\& 3). Environmental factors (namely climate and topography); and soils were considered in placing the soils into various suitability classes as proposed by
Sys and Verheye (1975). The annual rainfall of the area is reported to be $750 \mathrm{~mm}$ spread over 150 days in a year, hence sufficient for the production of these crops. The slope of the area is also suitable (less than 3\%). Procedure for placing the mapping units into suitability classes for cowpea and millet is given in Tables 4a and 4b. TUP2 and TUP3 are rated suitable for cowpea and millet. The soils have low organic matter content and low nitrogen content. TLL1 is rated not suitable for the crops due to limitation of wetness (poorly drained). 
Table 3. Some chemical properties of the soils of Dingyadi district used for classification

\begin{tabular}{|c|c|c|c|c|c|c|c|}
\hline Pedon & Horizon & $\begin{array}{l}\text { Depth } \\
\text { (cm) }\end{array}$ & $\begin{array}{l}\mathrm{pH} \\
\left(\mathrm{H}_{2} \mathrm{O}\right.\end{array}$ & $\%$ OM & Total N (g/kg) & CEC (cmolkg-1) & $\begin{array}{l}\text { Base Sat. } \\
(\%)\end{array}$ \\
\hline & & & TLL1 & Typic Endo & alfs & & \\
\hline & & & & & & 4.53 & 86 \\
\hline \multirow[t]{8}{*}{1} & Ap & $0-30$ & 7.6 & 2.68 & 0.10 & & \\
\hline & $A B$ & $30-49$ & 8.1 & 2.76 & 0.10 & 4.16 & 91 \\
\hline & B & $49-73$ & 8.2 & 2.64 & 0.09 & 4.52 & 83 \\
\hline & Bt1 & 73-104 & 7.5 & 1.32 & 0.08 & 4.52 & 78 \\
\hline & $\mathrm{Bt} 2$ & $104-110$ & 7.4 & 2.32 & 0.09 & 4.42 & 79 \\
\hline & & Average & 7.8 & 2.34 & 0.09 & 4.43 & 83 \\
\hline & & & \multirow{2}{*}{\multicolumn{3}{|c|}{ TUP2 Typic Haplustepts }} & & \\
\hline & & & & & & 3.42 & 96 \\
\hline \multirow[t]{7}{*}{3} & Ap & $0-18$ & 7.1 & 1.40 & 0.07 & & \\
\hline & $A B$ & $18-27$ & 6.9 & 2.60 & 0.06 & 3.48 & 93 \\
\hline & 2Bw1 & $27-66$ & 7.0 & 1.40 & 0.07 & 3.50 & 92 \\
\hline & 2Bw2 & $66-135$ & 7.1 & 1.44 & 0.06 & 3.48 & 89 \\
\hline & 2Bw3 & $135-204$ & 7.0 & 1.00 & 0.05 & 3.44 & 88 \\
\hline & & Average & 7.0 & 1.57 & 0.07 & 3.50 & 92 \\
\hline & & & \multicolumn{3}{|c|}{ TUP 3 Typic Ustorthents } & & \\
\hline \multirow[t]{4}{*}{5} & Ap & $0-11$ & 6.7 & 0.96 & 0.07 & 3.34 & 80 \\
\hline & $A B$ & $11-40$ & 6.8 & 1.84 & 0.07 & 3.32 & 91 \\
\hline & C & $40-43$ & 6.0 & 1.88 & 0.06 & 3.22 & 91 \\
\hline & & Average & 6.5 & 1.56 & 00.7 & 3.30 & 87 \\
\hline
\end{tabular}

Table 4a: Capability Classes of Soils of Dingyadi District for Cowpea Production

\begin{tabular}{llll}
\hline Soil mapping unit & TUP1 & TLL2 & TLL3 \\
\hline Mean Annual Temperature & S1 & S1 & S1 \\
Rainfall & S1 & S1 & S1 \\
Topography & S2 & S1 & S1 \\
Wetness & N1W & S1 & S1 \\
Texture & S2 & S2 & S2 \\
CEC & S1 & S2 & S2 \\
BS & S2 & S2 & S2 \\
OM & S3 & S3 & S3 \\
Aggregate Suitability & N1W & S2 & S2 \\
\hline
\end{tabular}

BS= Base saturation, OM=organic matter, CEC= Cation Exchange Capacity

Table 4b: Suitability Classes of Soils of Dingyadi District for Millet Production

\begin{tabular}{llll}
\hline Soil mapping unit & TUP1 & TLL2 & TLL3 \\
\hline Mean Annual Temperature & S1 & S1 & S1 \\
Rainfall & S1 & S1 & S1 \\
Topography & S2 & S1 & S1 \\
Wetness & Nsw & S1 & S1 \\
Texture & S2 & S2 & S3 \\
CEC & S1 & S2 & S2 \\
BS & S2 & S2 & S2 \\
OM & S3 & S3 & S3 \\
Aggregate Suitability & N1sw & S2 & S2 \\
\hline
\end{tabular}

S1= Highly suitable, S2= Moderately Suitable, S3= Marginally Suitable, N1= currently Not suitable 


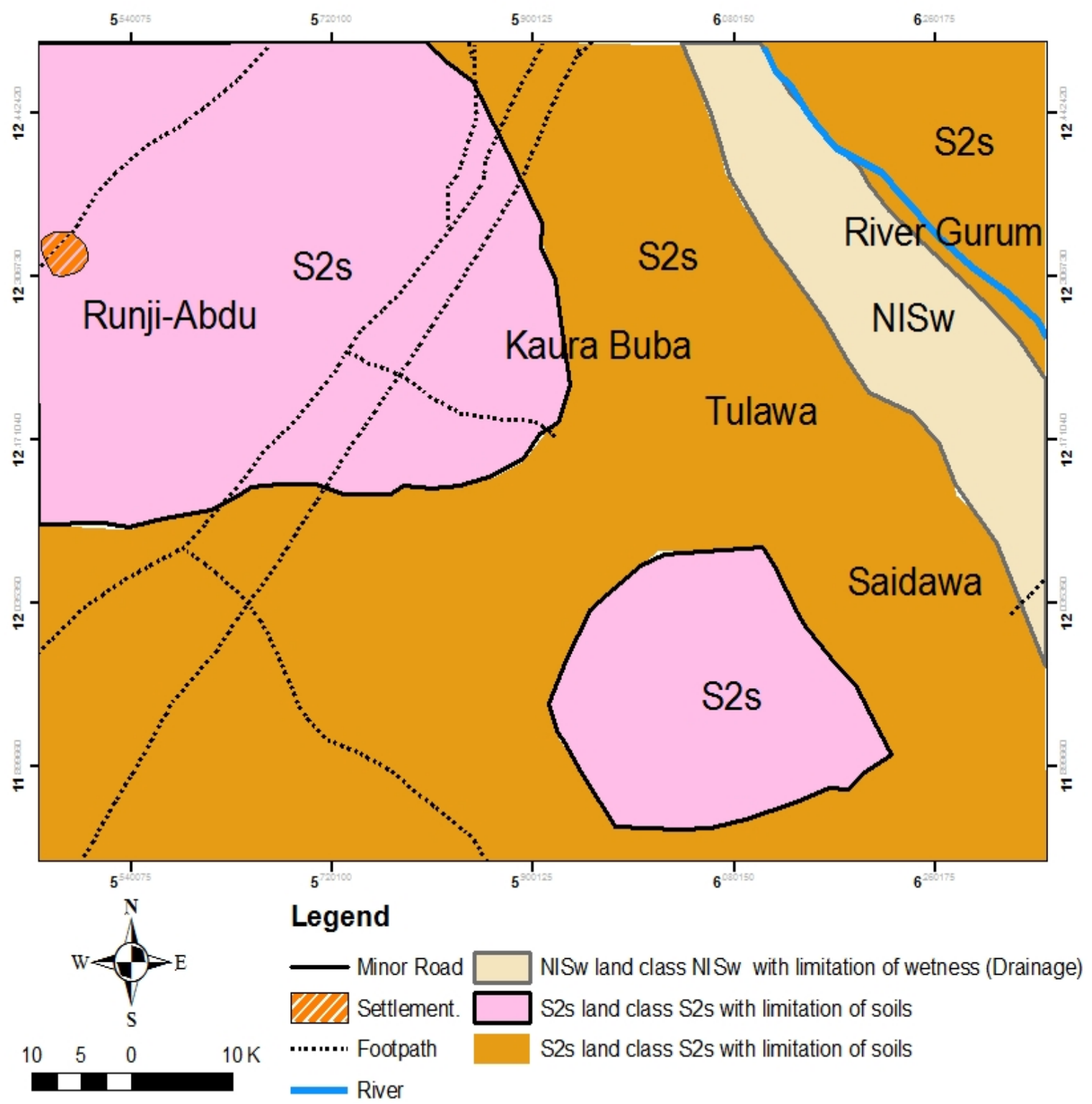

Figure 2: Land suitability map for cowpea and millet of an Agricultural landscape in Dingyadi district

Fertility Capability Classification of Soils of Dingyadi District

Fertility capability classification of an agricultural landscape of soils of Dingyadi area is presented in Table 5 and Figure 3. Soil unit TLL 1 is classified in fertility capability class LSg, LS indicates that the soils are predominantly loamy sand at the surface and subsurface while the $g$ modifier refers to limitation of poor drainage. This problem of poor drainage could limit the types of crops to be grown, unless if adequate surface and subsurface drainage is provided. Soil unit TUP 2 is classified in fertility capability class Lde, L indicates the soils are predominantly loam while the modifier $d$ refers to the annual dry period of at least 90 cumulative days in normal year, e indicates low CEC status of the soils (Table 3). Organic matter incorporation will help to improve the soil structure, aid moisture retention for crop uptake and enhances CEC of the soils. Soil unit TUP 3 is classified as Sde in fertility capability classification. $S$ indicates the soils are predominantly sandy both in the surface and subsurface. The modifier $d$ indicates an annual dry period of at least 90 days in normal year and $e$ indicates the low CEC status of the soils. 
Table 5: Fertility Capability Classification (FCC) and interpretation of soils of Dingyadi District

\begin{tabular}{|c|c|c|c|c|c|}
\hline $\begin{array}{l}\text { mapping } \\
\text { unit }\end{array}$ & Extent & types/subtypes & modifier(s) & $\begin{array}{l}\text { prevalent } \\
\text { fcc units }\end{array}$ & interpretations \\
\hline TUP1 & $\begin{array}{l}133 \mathrm{ha} \\
(26.6 \%)\end{array}$ & $\mathrm{L}$ & $\mathrm{Sg}$ & Lsg & $\begin{array}{l}\mathrm{L} \text {; imperfectly drained soils with loamy surface } \\
\text { and subsurface texture, low CEC and limitation } \\
\text { of poor drainage }(\mathrm{g}) \text {. drainage is essential }\end{array}$ \\
\hline TLL2 & $\begin{array}{l}220 \mathrm{ha} \\
(44.0 \%)\end{array}$ & $\mathrm{L}$ & De & Lde & $\begin{array}{l}\mathrm{L} \text {; well drained loamy }(\mathrm{L}) \text { soils with dry (Ustic } \\
\text { moisture regime) }(d) \text { and low CEC }(e) \text {.There is } \\
\text { need for organic matter incorporation. }\end{array}$ \\
\hline TLL3 & $\begin{array}{l}147 \text { ha } \\
(29.4 \%)\end{array}$ & S & De & Sde & $\begin{array}{l}\text { S: sandy texture }(d) \text { with limitations of dry } \\
\text { (Ustic moisture regime), low CEC (e). Organic } \\
\text { manure e.q. compost is essential here. }\end{array}$ \\
\hline
\end{tabular}

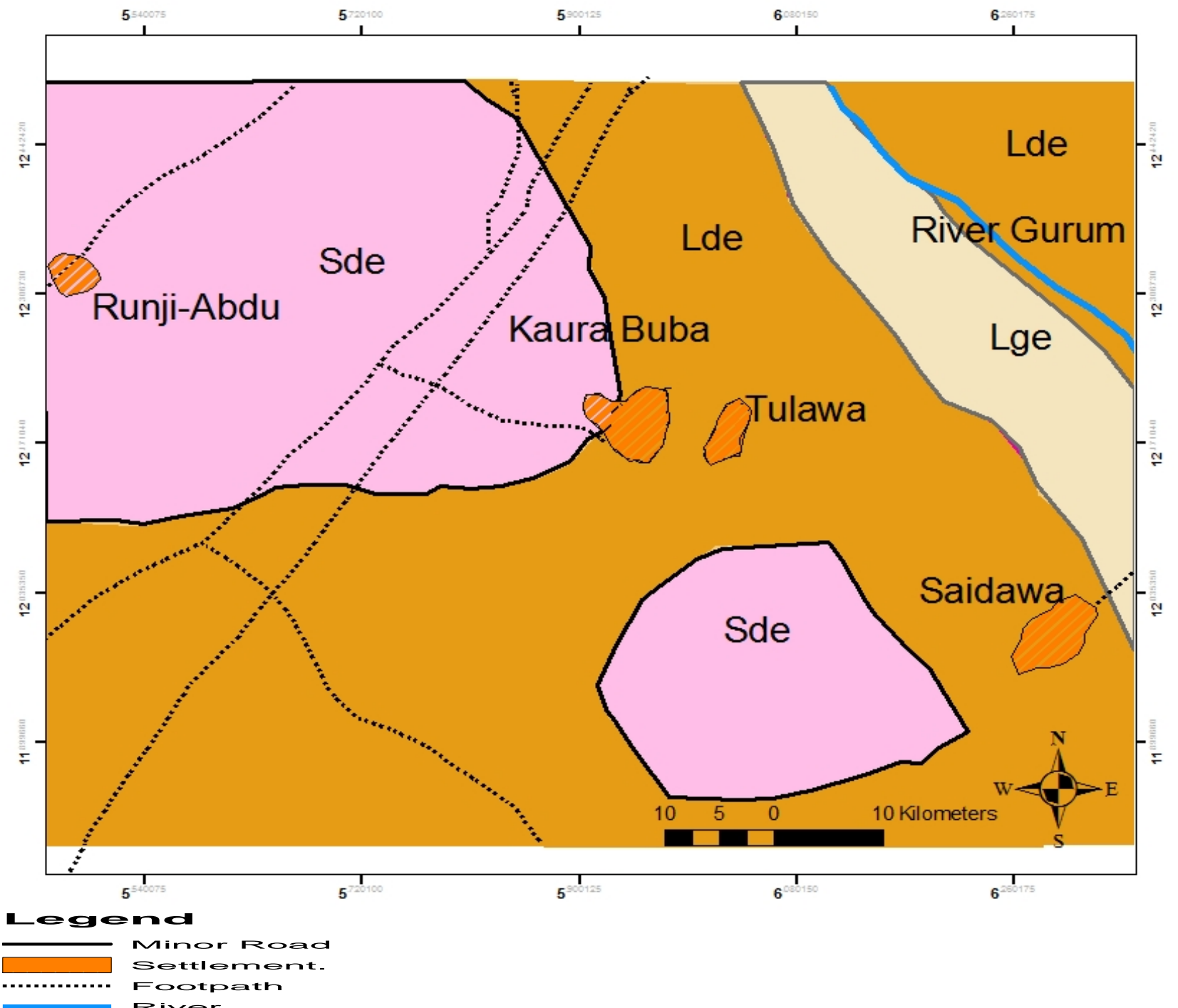

Figure 3: Soil fertility capability classification of soils of an Agricultural Landscape 


\section{CONCLUSION}

Land/soil evaluation was done using the USDA land capability classification, Fertility capability classification and suitability classification for millet and cowpea as the dominant crops produce in the area. The soils were classified into various Land capability classes of III and IV indicating that the soils are all good for agriculture. In land fertility capability classification (FCC) the soils were found to have limitation of fertility due to low CEC and in TLL 1 in addition to fertility problem has problem of drainage. The suitability of the soil was assessed for two major crops (Cowpea and pearl millet) grown in the area following the method of Sys and Verheye (1985) and were all found to be suitable except soil unit TLL1 because of limitation of wetness. Management practices such as periodic monitoring of soil quality, adding organic manure and guided inorganic fertilizer use have been recommended for improve productivity. Adequate provision of surface and subsurface drainage is needed for soil unit TLL1.

\section{REFERENCES}

Abdulkadir, A. (1998). Soil type and their management in the southern lake area, Nigeria. Proceedings of the $12^{\text {th }}$ National Irrigation and drainage Seminar on Irrigation and Sustainable Agriculture.IAR, ABU, Zaria, Nigeria. $14^{\text {th }}-16^{\text {th }}$ April, 1998. Pp334348

Blake G.R., and Hartge, K.H. (1986). Bulk density. In methods of Soil Analysis. Klute A. (Ed).Part 1. $2^{\text {nd }}$ ed. Agron. 9. ASA and SSA, Madison, W1.P.363375.

Dorronso. (2000). Soil evaluation: the role of soil science in land evaluation. Campus Fuentenueva press, Universidad de Granada, Spain.

FAO (2006). Guidelines for Soil Description, $4^{\text {th }}$ Edition, Rome, 109pp

FAO. (1995). Guidelines; Land Evaluation for rainfall agriculture. Soil Resources Management and Conservation Service, Land and Water Development Division Rome. FAO Soil Bulletin. 52 pp237.

FAO.(1985). Guidelines: Land evaluation for irrigated agriculture. Food and agricultural organization of the United Nations. Soils Bul., Rome, Italy P.55.

FDALR, 1985. The Reconnaissance Soil Survey of Sokoto State, Nigeria. Soil report. Federal Department of Agricultural Land Resources, Kaduna.
Gee, G.W. and Bauder, J.W. (1986). Particle -size analysis. In methods of soil analysis. A Klute (Ed). Part 1. $2^{\text {nd }}$ ed. Agron. ASA and SSSA, Madison WI.P383.

Harrison, M.N. (1987). Maize in the tropics. Longman, London, 400pp

Kowal, D. and Knabe, D.J. (1972) An Agroclimatological Atlas of the Northern State of Nigeria. Ahmadu Bello Univ. press, Zaria, Nigeria.

Maniyunda, L.M., Kparmwang, T., Raji, B.A., and Yaro, D.T. (2007). Land Suitability Evaluation of Haplustults For Rainfed Crop Production in A SubHumid Environment Of Nigeria. In Uyovbisere, E.O, Raji, B.A, Yusuf, A.A, Ogunwale, J.O, Aliyu, L. and Ojeniyi, S.O (Eds). Soil and water management for poverty alleviation and sustainable Envtironment. Proceedings of the $31^{\text {st }}$ annual conf. of SSSN/ABU Zaria Nig. Nov. $13^{\text {th }}$ to $17^{\text {th }}, 2006$.

Nelson, D.W. and E. Summers, (1982). Total C, organic matter. In page, A.L., Miller, R.H. and Keeny, D.R. (Eds) Method of Soil Analysis. Part 2. chemical and microbiological properties, $3^{\text {rd }} \mathrm{ed}$.

Ogunkunle A.O. (1993). Variation of some soil properties along two toposequences on quartile schist and banded gneiss in southern Nigeria. Geoderma 30(4): 397-402.

Ojanuga, A.G. (2006). Agro ecological zones of Nigeria Manual. National Special programme for food security and FAO. Pp 124.

Page, A. L., Miller, R.H. and Keeney, D.R. (1982). Methods of soil analysis (Eds) agron 9, part 2, ASA, Madison Wisconsin

Singh, B.R. and Babaji, G.A. (1989). Characteristics of the Soils in Dundaye District: the Fadama Soils of the University Dryland Farm. Nigeria Journal of Basic and Applied Science, 3(1): 7-16

Sombroek, W. G., and Zonneveld, I. S. (1971). Ancient Dunes Fields and Fluviatile Deposits in the Rima. Sokoto River Basin Soil Survey Paper No.5, Netherland Soil Survey Institute, Wageningen, pp109.

Sys, C., and Verheye, W. (1975). Principles of land evaluation in arid and semi arid regions. ICT State University, Ghent, Belgium.

Van Diepen, C.A., Van Keulen, H., Wolf, J. and Berkhout, J. A.A. (1991). Land Evaluation: From Intuition to Quantification. In: Advances in Soil Science (B. A. Stewart) (ed). Springer, New York, pp. 139-204. 
Verheye, W. H. (2000). Land Use and Land Cover- vol. 2- Land- Evaluation, Encyclopedia of life support Systems (EOLSS).

Vomocil, J.A (1965) Porosity. In C.A Black (ed) Method of Soil Analysis. Part 1 American Society of Agronomy. Monograph 9.pp299-314.
Wilding, L.P and Dress, L.R. (1983). Spatial variability and Pedology. In: L.P wilding, N.E Smack, and G.F. Hall (Eds) Pedogenesis and Soil Taxonomy. 1. Concepts and interactions. New York. Elsevier. PP 83-11 